\title{
PERAN ORANG TUA TERHADAP PERKEMBANGAN PRIBADI REMAJA ATAS PEMANFAATAN INTERNET DI KALANGAN REMAJA DI SMU ADVENT MAKASSAR
}

\author{
Vita Olivia Maruanaya \\ Ivan Th. J. Weismann
}

\begin{abstract}
ABSTRAK
Pokok masalah dalam penulisan ini adalah sejauh mana peran orang tua dalam perkembangan pribadi remaja atas pemanfaatan internet dikalangan remaja. Adapun tujuan yang ingin dicapai ialah untuk membahas peran orang tua dalam perkembangan pribadi remaja atas pemanfaatan internet dikalangan remaja. Penelitian ini mengambil sampel yang terdiri dari 40 orang tua atau 40 keluarga dan 40 siswa remaja. Sampel siswa remaja diambil dari siswa SMU Advent dan sampel orang tua dari orang tua siswa. Penulis menggunakan kuesioner dan wawancara sebagai teknik pengumpul data. Teknik analisis data ialah analisis statistic dengan program SPSS 15. Hasil penelitian ini ialah pengaruh peran orang tua kepada kualitas pribadi anak masih kurang, sehingga hanya memberikan pengaruh negatif kepada kualitas pribadi anak, sehingga anak kurang memakai internet untuk hal positif.
\end{abstract}

Kata kunci: Peran orang tua, kualitas pribadi, internet

\section{PENDAHULUAN}

\section{Latar Belakang Masalah}

Menurut pandangan Judith Allen Shelly, "secara arti luasnya, orang tua adalah wakil Allah bagi setiap anak." Jadi walaupun anak adalah merupakan individu baru yang hidup di dunia. Tetapi mereka tetap membutuhkan, malah masih sangat bergantung kepada orang tua. Makanya orang tua yang bertanggung jawab untuk memberikan pengajaran tentang kepercayaan sebagai pembangunan iman kepercayaan kepada Allah. Pada Matius $18: 5-6$,

Barangsiapa menyambut seorang anak seperti ini dalam namaKu, ia menyambut Aku. Tetapi barangsiapa menyesatkan salah satu dari anak-anak kecil ini yang percaya kepada-Ku, lebih baik baginya jika sebuah batu kilangan dikaitkan pada lehernya lalu ia ditenggelamkan ke dalam laut."

Disini sangat jelas kembali lagi orang-orang dewasa khususnya orang tua memiliki tanggung jawab yang sangat besar untuk memelihara serta memperhatikan pertumbuhan anak-anak Allah, dan jangan sampai membuat mereka tersesat karena ajaran atau kelakuan orang tua yang salah. Sehingga pemahaman mereka tentang Allah menjadi salah.

Selain pengajaran tentang kepercayaan yang dapat menjadi iman percaya mereka, dibutuhkan juga nilai-nilai moral karena "nilai-nilai moral ini adalah merupakan warisan dari leluhur yang merupakan perkembangan dari pengalaman-pengalaman hidup." Jadi kembali lagi sudah merupakan tanggung jawab orang tua sejak dini untuk memberikan pengajaran tentang nilai-nilai moral kepada anak. Dengan nilai-nilai moral yang diajarkan, kelak anak-anak yang sudah mengenal lingkungan dapat dilindungi dari pengaruh teman sebayanya dan godaan zaman yang semakin berkembang. Karena dengan nilai-nilai moral yang sudah diajarkan kepada mereka, mereka dapat mengambil keputusan sendiri. Sesuai dengan pandangan Linda dan Richard Eyre bahwa "jika anak-anak berangkat dari kondisi tanpa nilai, tanpa seseorang pun yang mengajari, tanpa sesuatu yang dapat dipelajari

\footnotetext{
${ }^{1}$ Judith Allen Shelly, Kebutuhan Rohani Anak, (Bandung : Yayasan Kalam Hidup, n.d) , 11

${ }^{2}$ Ibid.

${ }^{3}$ Linda dan Richard Eyre, Mengajarkan Nilai-Nilai Kepada Anak, (Jakarta : Gramedia Pustaka Utama,
} 1999), xviii 
mereka akan terkatung-katung tak tentu arah, dan hidup mereka tidak akan menjadi milik mereka." ${ }^{4}$

Tetapi kenyataannya ada anak yang telah mendapat pengajaran kepercayaan, dan telah mendapat pengajaran tentang nilai-nilai moral. Tetapi saat anak itu bertumbuh menjadi remaja, dan hadir pada perkembangan zaman. Dimana saat para remaja ini mengenal teknologi yang lagi berkembang saat ini, khususnya teknologi internet yang sudah menjadi konsumsi remaja setiap harinya. Tetapi apa yang terjadi adalah pemanfaatan internet yang negatif bagi remaja yang memberikan dampak negatif kepada remaja itu. Menurut pengakuan salah satu remaja yang sering menggunakan fasilitas internet, "kalau melihat gambar porno jarang, melihat video porno jarang, itu juga kalau ada info dari teman-teman kalau ada video yang baru." Inilah pemanfaatan internet yang negatif dan paling buruk bagi remaja, yaitu melihat gambar atau video porno. Ada juga pengakuan remaja yang memiliki komputer sendiri dirumah, dalam hal ini adalah laptop, "lebih senang duduk didepan komputer pada jam larut malam seperti dari jam sepuluh sampai jam dua dini hari." Ini berbahaya bagi remaja, bahayanya adalah dapat mengganggu kesehatan remaja itu sendiri, karena kurang istirahat. Aktifitasnya pada besok hari dapat terganggu, karena remaja kurang konsentrasi dalam melakukan aktifitasnya karena mengantuk. Ada juga remaja yang mengatakan "kalau main game jelas itu sudah menjadi hobi, apalagi kalau gamenya itu yang berkaitan dengan perang, baik itu menyusun strategi atau langsung menembak musuh, itu jelas yang paling menyenangkan karena seru dan permainan itu mengasah otak." " Kekerasan yang ditonjolkan pada game inilah, yang dapat membahayakan mental remaja, makanya terjadi perkelahian antar kelompok, ini karena bagi mereka kekerasan itu wajar. Tidak jarang ada anak remaja yang bersedia bolos karena hanya untuk pergi ke warnet, alasan mereka karena mereka bosan ke sekolah. Dampak buruk remaja jadi ketagihan sehingga pelajaran mereka tertinggal dan nilai mereka jadi merosot.

Seyogyanya sejak dini anak memang harus mendapat pengajaran tentang kepercayaan untuk menumbuhkan iman percayanya kepada Allah, dalam memenuhi kebutuhan rohani. Anak juga mendapat pengajaran tentang nilai-nilai moral agar kelak anak-anak yang akan mengenal lingkungan luar tidak akan terpengaruh oleh lingkungan. Tetapi saat anak itu tumbuh menjadi remaja, dan berada pada zaman yang berkembang. Di mana teknologi yang semakin maju, khususnya internet. Sehingga remaja menjadi begitu mengerti teknologi internet, dan terjadi pemanfaatan internet yang negatif bagi remaja dan internet juga memberikan dampak negatif bagi remaja.

Dengan melihat kenyataan ini, maka permasalahannya adalah sejauh mana peran orang tua terhadap perkembangan pribadi remaja atas pemanfaatan internet dikalangan remaja. Pada Amsal 22:6 mengatakan "Didiklah orang muda menurut jalan yang patut baginya, maka pada masa tuanyapun ia tidak akan menyimpang dari pada jalan itu." ${ }^{8}$ Hikmat yang sudah sejak dulu kala berlaku dalam kitab suci disahkan secara mutlak oleh penyelidikan psikologis, yaitu bahwa pengertian rohani yang dikembangkan pada anak sampai pada remaja, justru menjadi dasar bagi iman kepercayaan pada masa dewasa. "Para orang tua dapat bertumbuh menjadi orang-orang yang mengasihi Allah dan dapat menyesuaikan diri dengan baik pada lingkungannya." Sebelum orang tua menjalankan perannya kepada anak, maka orang tua harus melihat pada dirinya sendiri. Melihat pada diri sendiri sudah tumbuh dalam Kristus, melihat diri sendiri mengasihi Allah, dan 1999), xiii

${ }^{4}$ Linda dan Richard Eyre, Mengajarkan Nilai-Nilai Kepada Anak, (Jakarta : Gramedia Pustaka Utama,

\footnotetext{
${ }^{5}$ Age, Wawancara oleh Penulis, Makassar, 01 Agustus 2009

${ }_{7}^{6}$ Jessica, Wawancara oleh Penulis, Makassar, 01 Agustus 2009

${ }^{7}$ Andre, Wawancara oleh Penulis, Makassar, 01 Agustus 2009

${ }^{8}$ Ibid. , 16

${ }^{9}$ Clyde M. Narramore, Ed.D. Menolong Anak Anda Bertumbuh dalam Iman, (Bandung : Yayasan Kalam
} Hidup, 1961), 7 
melihat diri sendiri dapat menyesuaikan dengan lingkungan, dalam artian bahwa orang menerima perkembangan zaman, dan dapat menyesuaikan diri dengan perubahan yang ada. Inilah yang harus dimengerti terlebih dahulu oleh orang tua, dalam memenuhi kualifikasi orang tua yang berkualitas. Karena hanya orang tua yang berkualitas yang dapat memenuhi perannya dalam perkembangan anak yang memiliki kepribadian yang berkualitas.

Menurut Erikson dalam teori perkembangan anak menjelaskan bahwa "kehidupan emosi dan kualitas hubungan-hubungan perorangan menjadi landasan yang penting untuk memberi bentuk terhadap perkembangan kepribadian selanjutnya." ${ }^{\prime 0}$ Orang tua yang mengasihi Kristus, pasti dapat mengerti akan perannya pada anak, dan hubungan orang dengan anak yang berlandaskan kasih sayang inilah yang merupakan kehidupan emosi antara anak dan orang tua yang merupaka sesuatu yang penting untuk perkembangan pribadi anak. Diperkuat dengan tanggapan Singgih D. Gunarsa yaitu "orang tua merupakan tokoh pusat, karena mereka yang berperan besar, langsung atau kadang-kadang tidak langsung, berhubungan terus menerus dengan anak, dalam mempengaruhi perkembangan aspek moral dan rohani anak."ll

\section{Pokok Masalah}

Dengan melihat penjelasan latar belakang diatas maka yang menjadi pokok masalah dalam penulisan Penelitian ini adalah: Sejauh mana peran orang tua dalam perkembangan pribadi remaja atas pemanfaatan internet dikalangan remaja.

\section{Tujuan Penulisan}

Adapun tujuan yang ingin dicapai dalam penulisan ini : Untuk membahas peran orang tua dalam perkembangan pribadi remaja atas pemanfaatan internet dikalangan remaja.

\section{Manfaat Penulisan}

Adapun manfaat yang diperoleh dari penulisan ini adalah: Pertama, untuk memberikan kajian dan gambaran kepada orang tua tentang perkembangan pribadi remaja yang berkualitas. Kedua, dengan mengetahui konsep yang benar maka anak tumbuh menjadi remaja yang memiliki kepribadian yang berkualitas dan matang untuk menghadapi perkembangan teknologi.

\section{Gambaran Umum Lokasi Survei}

\section{METODOLOGI PENELITIAN}

\section{Latar Belakang Sekolah}

Sekolah Advent Makassar merupakan sekolah dibawa Yayasan Advent Hari Ketujuh. Yayasan Advent Hari Ketujuh pada awalnya mendirikan gereja, tetapi kemudian pihak yayasan berinisiatif mendirikan Sekolah Dasar (SD) dan Sekolah Menengah Pertama (SMP). Tetapi kemudian pada tahun 2001, tepatnya "tanggal 13 Juli 2001 berdirilah Sekolah Menengah Umum (SMU). Tetapi Akte pengesahan berdirinya Sekolah Menengah Umum (SMU) baru keluar pada Februari 2002". 12 Jadi SMU Advent Makassar tergolong sekolah yang masih baru.

\section{Staf Pengajar, Siswa, dan Fasilitas}

"Adapun staf pengajar yang ada di SMU Advent Makassar berjumlah 13 orang pengajar, dan semua staf pengajar aktif mengajar." "13 Mulai dari Pengajar IPA, yaitu mata pelajaran Fisika, Kimia, dan Biologi masing-masing satu guru. Pengajar IPS, yaitu mata pelajaran Ekonomi, Akuntasi, Sejarah, Antropologi, Sosiologi dan Tata Negara masingmasing satu guru dan mata pelajaran matematika ,bahasa Indonesia dan bahasa Inggris

\footnotetext{
${ }^{10}$ Singgih D. Gunarsa, Dasar dan Teori Perkembangan Anak, (Jakarta : Bpk Gunung Mulia, 1982), 107

${ }^{11}$ Singgih D. Gunarsa, Psikologi Praktis : Anak, Remaja, dan Keluarga, (Jakarta : Bpk Gunung Mulia, 1991),

${ }^{12}$ Ibu Delly (Kepala Sekolah), Wawancara Oleh Penulis, Makassar, 26 Mei 2009

${ }^{13}$ Ibid
} 
masing-masing satu guru. Adapun jumlah siswa yang belum termasuk kelas tiga adalah berjumlah 61 siswa. "Mulai kelas satu berjumlah 23 siswa, dan kelas dua berjumlah 38 siswa, di mana kelas dua sudah dibagi dua jurusan yaitu jurusan IPS berjumlah 21 siswa dan jurusan IPA berjumlah 17 siswa". ${ }^{14}$ Adapun fasilitas-fasilitas yang dimiliki sekolah, yaitu laboratorium IPA, laboratorium komputer yang dimana sudah ada fasilitas Internet, perpustakaan, lapangan basket dan lapangan sepak bola.

\section{Jenis Penelitian}

Jenis penelitian yang digunakan adalah penelitian kuantitaf. Penelitian kuantitatif adalah "Penelitian yang berstandar pada kuantifikasi dalam pengumpulan dan analisis data untuk menguji hipotesis yang telah ditetapkan". 15 Penelitian ini berusaha menjelaskan pengaruh orang tua terhadap perkembangan dan pertumbuhan kualitas pribadi anak atas pemanfaatan teknologi internet di kalangan remaja.

\section{Populasi dan Sampel}

Adapun penelitian ini menggunakan populasi dan sampel. "Populasi adalah kelompok dimana seorang peneliti akan memperoleh hasil penelitian yang dapat disamaratakan (digeneralisasikan)". ${ }^{16}$ Populasi penelitian ini ialah para orang tua dan anak atau siswa remaja yang ada di SMU Advent Makassar. Tetapi penulis menggunakan penelitian sampel. "Sampel adalah proses pemilihan sejumlah individu atau dengan kata lain penarikan sebahagian dari populasi untuk mewakili seluruh populasi." ${ }^{, 7}$ Jumlah siswa ada 61 orang, dari kelas satu ada 23 orang, dari kelas dua yaitu kelas IPA 17 orang, dan kelas IPS 21 orang. Dalam penelitian akan mengambil sampel yang terdiri dari 40 orang tua atau 40 keluarga dan 40 siswa remaja. Sampel siswa remaja diambil dari siswa SMU Advent dan sampel orang tua dari orang tua siswa.

\section{Teknik Pengumpulan Data}

Dalam penelitian lapangan, penulis menggunakan kuesioner dan wawancara sebagai teknik pengumpul data. Peneliti memberikan kuesioner kepada orang tua dimana isinya yang menjelaskan pertama, peran orang tua terhadap kualitas pribadi remaja, kedua, peran orang tua terhadap pemanfaatan internet dikalangan remaja.dan koesioner kepada siswa yang isinya menjelaskan pertama, kualitas pribadi remaja, kedua, pemanfaatan internet dikalangan remaja yang terdiri dari positif dan negatif. Kuesioner diberikan kepada orang tua untuk mengetahui sejauh mana pengaruh peran orang tua terhadap perkembangan pribadi remaja dan peran orang tua terhadap pemanfaatan intenet. Setelah itu kuesioner diberikan kepada remaja untuk mengetahui sejauh mana peran orang tua terhadap perkembangan pribadi remaja dan mengetahui pemanfaatan internet dikalangan remaja.

\section{Teknik Analisis Data}

Teknik analisis data yang digunakan dalam penelitian ini ialah statistik dengan rumus analisis regresi untuk mencari sejauh mana peran orang tua terhadap perkembangan pribadi remaja dilihat dari dua sisi, pada orang tua dan pada remaja. Mencari sejauh mana pemanfaatan teknologi internet dikalangan remaja. Hubungan orang

\footnotetext{
${ }^{14}$ Ibid

${ }^{15}$ Andreas B. Subagyo, Pengatar Riset Kuantitatif dan Kualitatif, (Bandung : Yayasan Kalam Hidup, 2004),

${ }^{16}$ Sumanto, Metodologi Sosial Dan Pendidikan, (Yogyakarta : Andi Offset, 1990), 23

${ }^{17}$ Winarno Surakhmad, Dasar e Teknik Research Pengantar Metodologi Ilmiah, (Bandung : Tarsita, 1978),
} 
tua dan anak; hubungan remaja dan pemanfaatan teknologi internet dikalangan remaja. Pengaruh kedua atribut atas perkembangan pribadi remaja dan pemanfaatan internet dikalangan remaja akan dianalisis dalam program SPSS15.

\section{PEMBAHASAN HASIL PENELITIAN}

Dalam bab ini, penulis akan membahas hasil penelitian yang dilakukan penulis melalui pembagian angket kepada responden dimana adalah siswa dan orang tua SMU Advent Makassar dan sudah berhasil diisi oleh responden. Jumlah angket yang diberikan kepada responden berjumlah 40 siswa, yaitu 25 siswa kelas X, 7 siswa kelas XII IPA, dan 8 siswa Kelas XII IPS dan 40 orang tua dari masing-masing siswa.

Data Kualitas Pribadi Dari responden yang telah diperoleh penulis dalam bentuk tabel distribusi relatif, dapat dilihat pada lampiran. Dari data diatas terlihat jumlah poin terendah pada kualitas pribadi yaitu 9 poin, dan ada 2,5 persen anak yang dapat di frekuensikan l. ini dapat dikatakan masih ada anak yang memiliki kualitas pribadi yang rendah. Sedangkan jumlah poin tertinggi adalah 22 poin, dan 2,5 persen, memiliki frekuensi 1. pada tingkat tertinggi justru hanya beberapa persen saja anak yang memiliki pribadi yang berkualitas. Berarti diatas 9 poin dan dibawa 22 poin yaitu $10,13,15,16,17,18,19,20,21$ diisi dengan persen yang cukup tinggi dan frekuensi anak yang cukup tinggi. Jadi jumlah anak yang memiliki poin kulitas pribadi yang rendah lebih banyak daripada jumlah anak yang memiliki jumlah poin yang cukup tinggi.

Dari pertanyaan angket yang diberikan, yang sebagian besar menjelaskan kebutuhan anak dari beberapa tehap yang mereka sudah lewati untuk memenuhi kebutuhan dalam proses pembentukan kualitas pribadi, padahal tahapan itu sudah mereka lewati. Berarti pada tahapan saat anak lewati, orang tua kurang berperan dalam pembentukan kualitas pribadi anak. Hanya sebagian anak yang menjawab, seadanya saja yang mereka butuhkan. Karena tahapan yang mereka lewati berjalan dengan baik dengan peran orang tua didalamnya. Jadi anak merasa kualitas pribadi pada peratnyaan yang diberikan sudah terpenuhi. Pertanyaan-pertanyaan pada angket untuk siswa dapat dilihat pada lampiran.

Data pengaruh orang tua dari responden yang diperoleh penulis dalam bentuk tabel, dapat dilihat pada lampiran. Bandingkan dengan data kualitas pribadi. Pada data tabel terlihat poin yang terendah adalah 16, memiliki frekuensi 3 dan 7,5 persen. Ternyata ada beberapa orang tua yang tidak terlalu berperan dalam proses pembentukan pribadi anak yang berkualitas. Sedangkan pada poin 36 sebagai poin tertinggi, terdapat frekuensi 4 dan 10 persen. Berarti ada beberapa orang tua yang cukup berperan dalam proses pembentukan pribadi anak yang berkualitas, ini termasuk jumlah frekuensi yang rendah dan jumlah persen yang rendah. Seharusnya peran orang tua kepada pembentukan pribadi anak meningkat. Tetapi ada jumlah poin yang dibawa jumlah poin tertinggi, tepatnya berada diantara jumlaj poin tertinggi dan terendah yaitu 24, 26, 27, 28, 29, 30, 31, 32, 33, 34 , dan 35. memiliki jumlah frekuensi yang cukup tinggi dan persen yang tinggi, berarti jelas ada beberapa orang tua yang tidak terlalu berperan dalam proses pemebentukan pribadi anak yang berkualita. Jumlah frekuensi yang cukup tinggi dan persen yang cukup tinggi berbanding terbalik dengan beberapa orang tua yang ikut berperan dalam pembentukan pribadi anak yang berkualitas yang memiliki jumlah frekuensi rendah dan persen yang rendah.

Pantaslah kalau jumlah poin anak tertinggi memilki frekuensi yang rendah dan persen yang rendah, hanya beberapa anak yang merasa orang tua memberikan kebutuhan mereka dalam pembentukan pribadi yang berkualitas. Sesuai dengan jumlah poin tertinggi pada peran orang tua memiliki frekuensi yang rendah dan persen yang rendah. Hanya beberapa orang tua yang berperan dalam memenuhi kebutuhan anak dalam proses pembentukan pribadi anak yang berkualitas. 
Data yang menjelaskan tentang anak yang memakai internet untuk hal positif , dapat dilihat pada lampiran. Dari data table terlihat jumlah poin terendah pada pemanfaatan internet untuk hal positif yaitu 17, frekuensi 1, dan 2,5 persen. Ini berarti ada anak yang tidak memakai internet untuk hal positif, karena ada juga anak yang jumlah poinnya rendah. Sedangkan jumlah poin tertinggi adalah 52, frekuensi 1, dan 2,5 persen. Berarti sangat sedikit atau hanya beberapa anak yang memakai internet untuk hal positif. Berarti diatas jumlah poin terndah adalah 17 dan dibawa jumlah poin tertinggi adalah 52 yaitu 20,21, 22, 24, 26, 27, 29, 31, 34, 35, 36, 38, 39, dan 41 masing-masing memiliki frekuensi yang cukup tinggi melebihi frekuensi untuknilai tertinggi. Ini berarti masih banyak anak yang tidak menggunakan internet untuk hal positif. Jumlah anak yang memakai internet untuk hal positif lebih sedikit, daripada jumlah anak yang tidak memakai internet untuk hal positif.

Dari pertanyaan angket yang diberikan, sebagian besar menjelaskan apa anak pernah memakai internet untuk hal-hal positif, misalnya belajar. Rata-rata anak menjawab pernah, kadang-kadang, atau tidak pernah atau jarang. Kurang ditemukan jawaban selalu. Ini berarti jelas memang ada kebanyakan anak tidak terlalu menyukai menggunakan internet untuk hal positif, dan hanya sedikit anak yang memakai internet untuk hal positif. Padahal banyak hal-hal positif bisa didapatkan di internet, salah satunya ilmu pengetahuan. Ilmu pengetahuan ini sangat penting untuk anak yang masih sekolah. Ilmu pengetahuan yang bisa diakses dapat menunjang pelajaran dari sekolah. Selain itu mereka bisa mendapatkan teman-teman baru. Selain itu mereka bisa menambah koleksi musik atau lagu, game, atau video yang keren-keren, semua itu bisa didownload di internet. Jadi tetap mengikuti perkembangan jaman.

Data yang menjelaskan tentang anak yang memakai internet untuk hal negative dan dampak internet kepada anak, dapat dilihat pada lampiran. Pada data tabel terlihat poin yang terendah adalah 42, frekuensi 1 dan 2,5 persen. Poin ini menjelaskan ada anak yang tidak memakai internet untuk hal negatif, dan internet tidak memberikan dampak negatif kepada anak. Tetapi jelas hanya sebagaian anak yang tidak memakai internet untuk hal negatif atau anak tersebut tidak terkena dampak negatif dari internet. Tetapi ada poin tertinggi yaitu 1l8, frekuensi 2, dan 5,0 persen. Berarti ada anak yang memakai internet untuk hal negatif dan terkena dampak negatif dari internet. Sebagian besar anak menggunakan internet untuk hal negatif atau terkena dampak negatif dari internet, bahkan sampai jumlah frekuensinya dan jumlah persen lebih besar daripada jumlah frekuensi pada anak yang jumlah poinnya rendah. Pada poin 42 yang dinyatakan lebih rendah, memiliki frekuensi 1 dan 2,5 persen, sedangkan pada poin tertinggi yaitu 118 memiliki frekuensi 2 dan 5,0 persen. Berarti diatas nilai terendah dan dibawa nilai tertinggi yaitu 53, 56, 57, 5, 59, 60, 61, 63, 64, 66, 68, 69, 70, 71, 73, 74, 75, 76, 77, 78, 79, 80, 81, dan 82, masing-masing memiliki frekuensi dan jumlah persen yang cukup tinggi. Jadi jumlah memakai internet untuk hal negatif dan anak yang terkena dampak negatif memiliki jumlah yang tinggi. Hampir sebagian besar anak yang memakai internet untuk hal negatif atau terkena dampak negatif dari internet.

Internet memang adalah gudangnya ilmu pengetahuan banyak hal-hal positif yang didapatkan dari internet, tetapi ada juga hal-hal negatif dari internet yaitu pornografi, video, maupun gambar dapat diakses lewat internet. Adapun dampak negatif yang bisa terjadi pada anak yaitu anak akan memikirkan atau membayangkan apa yang sudah mereka lihat. Selain itu jika pemakaian internet secara berlebihan sampai menyita waktunya untuk istirahat, maka terjadi penurunan konsentrasi, nilai-nilai pelajaran mereka akan menurun bahkan sampai prestasi mereka akan menurun, karena anak mengalami kantuk yang berkepanjangan, ada juga damapk negatif lain yang bisa didapatkan oleh anak. 
Hubungan Peran Orang Tua Dan Kualitas Pribadi Anak

Data berikut menjelaskan tentang hubungan peran orang tua dan kualitas pribadi anak

Coefficients(a)

\begin{tabular}{|c|c|c|c|c|c|c|}
\hline \multirow{2}{*}{\multicolumn{2}{|c|}{$\overline{\text { Mode }}$}} & \multicolumn{2}{|c|}{$\begin{array}{c}\text { Unstandardized } \\
\text { Coefficients }\end{array}$} & \multirow{2}{*}{$\begin{array}{c}\text { Standardized } \\
\text { Coefficients } \\
\text { Beta } \\
\end{array}$} & \multirow{2}{*}{$\begin{array}{l}\mathrm{t} \\
\mathrm{B}\end{array}$} & \multirow{2}{*}{$\begin{array}{c}\text { Sig. } \\
\text { Std. Error }\end{array}$} \\
\hline & & B & Std. Error & & & \\
\hline \multirow[t]{2}{*}{1} & (Constant) & 20.265 & 2.658 & & 7.625 & .000 \\
\hline & $\begin{array}{l}\text { Peran_orangtu } \\
\text { a }\end{array}$ & -.112 & .088 & -202 & -1.274 & 210 \\
\hline
\end{tabular}

a Dependent Variable: Kualitas_Pribadi

$\mathrm{Y}=\mathrm{a}+\mathrm{bX}$

$\mathrm{Y}=7,625+(-1,274) \mathrm{X}$

$\mathrm{Y} \quad=$ Kualitas pribadi

$\mathrm{X} \quad=$ Peran orang tua

Jika orang tua yang berperan dalam pembentukan pribadi anak yang berkualitas meningkat, maka meningkat pula anak yang memiliki kualitas pribadi yang berkembang. Tetapi jika orang tua yang berperan dalam pembentukan pribadi anak yang berkualitas mengalami penurunan, maka sedikit pula anak yang memiliki kualitas pribadi yang berkembang.

Terlihat pada data tabel, angka negatif pada peran orang tua, berarti hubungan orang tua kepada anak dalam pembentukan kualitas rendah, atau kurang berkembang. Dalam pertanyaan yang diberikan kepada orang tua berkaitan dengan pemberian kepada anak dalam memenuhi kebutuhan kualitas pribadi anak. Terbukti sangat rendah peran orang tua dalam pemberian untuk memenuhi kebutuhan. Disini contohnya yaitu dalam pemberian kesempatan untuk mengembangkan sikap kemandirian kebanyakan orang tua menjawab jarang atau tidak pernah. Ini jelas kebanyakan orang tua kurang memberikan kesempatan kepada anak. Padahal anak sangat membutuhkan peran serta orang tua dalam pembentukan pribadi anak khususnya pemberian kesempatan kepada anak dalam mengembangkan kepribadian agar pribadi berkualitas.

Agar angka tidak menunjukkan negatif pada peran orang tua untuk hubungan orang tua kepada kualitas anak maka perlu ada peran orang tua kepada tahapan-tahapan yang dilewati anak untuk pembentukan kualitas pribadi anak seperti pada teori Erikson. Menurut

Erikson bahwa "manusia ketika dilahirkan mempunyai potensi untuk menjadi baik atau menjadi buruk". Jadi menusia yang lahir tidak langsung bersifat baik atau buruk, tapi masih berpotensi untuk baik atau buruk. ${ }^{, 18}$ Karena itu orang tua perlu memberi perhatian kepada perkembangan dan kepribadian anak, dimana sifat yang baik atau buruk yang akan menonjol. Oleh karena itu sangat mempengaruhi ke depan kepribadian anak itu. Itulah Erikson mengatakan kehidupan emosi dan kualitas hubungan-hubungan perorangan menjadi landasan yang penting untuk memberi bentuk terhadap perkembangan kepribadian selanjutnya." ${ }^{19}$ Karena itu orang tua menjadi tempat anak belajar berkomunikasi, dan anak sangat bergantung kepada orang tua. Jadi orang tua perlu sadar bahwa peran mereka sebagai orang tua dalam tahapan-tahapan yang anak lewati itu sangat penting dalam pembentukan kepribadian anak.

\footnotetext{
${ }^{18}$ Gunarsa, Dasar Dan teori perkembangan anak, 105.

${ }^{19}$ Ibid
} 
Sebagai bentuk komunikasi orang tua kepada anak menyatakan mengasihi mereka. "Sebelum memberi nasehat, baik jika kita menyampaikan perasaan bahwa kita mencintai dia karena dia adalah anak kita." ${ }^{20}$ Apa salahnya jika orang tua mengasihi mereka, walaupun kadang-kadang mereka membuat kesalahan, yang membuat orang tua jadi terluka. "Cinta adalah dasar dari bangunan relasi orang tua dan anak remaja." ${ }^{21}$ cinta adalah dasar komunikasi dengan remaja, karena cinta orang tua berusaha tetap menjaga komunikasi dengan remaja.

\section{Pengaruh Peran Orang Tua dan Kualitas Pribadi Anak Atas Pemanfaatan Internet yang positif}

Data berikut menjelaskan pengaruh peran orang tua dan kualitas pribadi anak atas pemanfaatan internet yang positif.

\section{Coefficients(a)}

\begin{tabular}{|c|c|c|c|c|c|c|}
\hline \multirow{2}{*}{\multicolumn{2}{|c|}{ Mode }} & \multicolumn{2}{|c|}{$\begin{array}{c}\text { Unstandardized } \\
\text { Coefficients }\end{array}$} & \multirow{2}{*}{$\begin{array}{c}\text { Standardized } \\
\text { Coefficients } \\
\text { Beta }\end{array}$} & \multirow[b]{2}{*}{ B } & \multirow{2}{*}{$\begin{array}{c}\text { Sig. } \\
\text { Std. Error }\end{array}$} \\
\hline & & B & Std. Error & & & \\
\hline \multirow[t]{3}{*}{1} & (Constant) & 52.491 & 10.860 & & 4.833 & .000 \\
\hline & $\begin{array}{l}\text { Kualitas_Priba } \\
\text { di }\end{array}$ & -.968 & .417 & -.364 & -2.324 & .026 \\
\hline & $\begin{array}{l}\text { Peran_orangtu } \\
\text { a }\end{array}$ & -.206 & .231 & -.140 & -.894 & .377 \\
\hline
\end{tabular}

a Dependent Variable: Positif_Internet

$\mathrm{Y}=4,833+(-2,324) \mathrm{Xl}+(-0,894)$

$\mathrm{Y}=$ Positif internet

$\mathrm{Xl}=$ Kualitas pribadi

$\mathrm{X} 2$ = Peran orang tua

Jika peran orang tua meningkat dalam pembentukan pribadi anak kearah pribadi yang berkualitas, maka meningkat pula anak yang memiliki kepribadian yang berkualitas sehingga meningkat pula anak yang memakai internat untuk hal-hal positif.

Tetapi pada data tabel, terlihat adanya sebagian saja anak yang memakai internet untuk hal positif. Ini karena faktor peran orang tua yang memberikan dampak negatif kepada kualitas pribadi anak, sehingga ada hubungannya dengan pemakaian internet untuk hal-hal positif.

Dari hasil angket baik orang tua dan anak, menjelaskan kurangnya peran orang tua pada setiap tahapan atau masa yang dilewati anak dalam proses pembentukan kepribadian anak, sehingga ditemukan pada anak yang menjawab pertanyaan angket bahwa kepribadian anak kurang berkembang kearah kepribadian yang berkualitas. Makanya anak kurang memakai internet untuk hal-hal positif, itu karena kurangnya kesadaran atas kegunaan dari internet yang sebenarnya. Ini karena orang tua kurang berperan dalam mengarahkan anak untuk memakai internet untuk hal-hal positif.

Erikson mengatakan "hubungan antargenerasi, yang dia sebut hubungan timbal balik (mutuality). Disini hubungan timbal balik dijelaskan sebagai hubungan orang tua dengan anak, begitu juga hubungan anak dan orang tua." ${ }^{22}$ Dari orang tua anak dapat belajar, dari anak orang tua dapat belajar. Orang tua bisa belajar tentang internet

${ }^{20}$ Julianto Simanjuntak dan Roswitha Andraha, Mendidik Anak sesuai zaman dan kemampuannya, (Tangerang : Lk3, 2007), 15

${ }^{21}$ Ibid. , 97

${ }^{22}$ Ibid. , 385 
berkaitan dengan hal-hal positif kepada anak. Perkembangan teknologi internet yang makin maju, dan generasi sekarang pasti lebih banyak belajar dan mengikuti perkembangan teknologi. Ini berarti mereka lebih banyak tahu tentang perkembangan teknologi internet, karena itu orang tua dapat belajar dari anak. Erikson mengatakan bahwa anak-anak pun juga mempengaruhi perkembangan kejiwaan orang tua mereka." ${ }^{23}$ Makanya jangan pernah menganggap anak adalah manusia yang tidak tahu apa-apa, sampai orang tua merasa tidak pantas jika orang tua belajar dari anak. Padahal orang tua tidak sadar bahwa kadang-kadang anak justru lebih banyak tahu dari orang tua.

"Sebagai orang tua, anda perlu secara aktif mempelajari bagaimana anda dapat memberikan saran mengenai situs-situs yang dapat mereka kunjungi di web untuk menemukan informasi yang mereka cari." ${ }^{24}$ Pengetahuan tentang perkenbangan internet itu sangat perlu bagi orang tua, karena agar orang tua dapat mengerti dampak apa yang diberikan internet. Jika orang tua sudah mengetahui, maka orang tua dapat memberikan saran kepada remaja situs-situs apa yang menarik. "Belajar menerima mereka apa adanya." ${ }^{25}$ Mungkin saat orang tua memberikan saran, remaja sulit menerima saran itu. Karena itu orang tua harus bisa memahami remaja dengan sagala perubahan yang terjadi pada remaja. Pahami jika ini demi kebaikan remaja. "Daya ingat cukup baik tetapi menuntut alasan." ${ }^{26}$ Walapun remaja memberontak terhadap saran-saran yang diberikan pada saat diskusi, tetapi saran positif itu tetap remaja ingat. Dengan alasan yang kuat, yang diberikan kepada remaja maka dengan sendirinya mereka akan mengakuinya. Dengan begitu akan meningkat remaja yang memakai internet untuk hal positif dan memberikan dampak positif kepada remaja.

\section{Pengaruh Peran Orang Tua dan Kualitas Pribadi Anak atas Pemanfaatan Internet yang Negatif}

Data berikut menjelaskan tentang pengaruh peran orang tua dan kualitas pribadi anak atas pemanfaatan internet yang negatif.

\section{Coefficients(a)}

\begin{tabular}{|c|c|c|c|c|c|c|}
\hline \multirow{2}{*}{\multicolumn{2}{|c|}{$\begin{array}{l}\text { Mode } \\
1 \\
\end{array}$}} & \multicolumn{2}{|c|}{$\begin{array}{l}\text { Unstandardized } \\
\text { Coefficients }\end{array}$} & \multirow{2}{*}{$\begin{array}{c}\text { Standardized } \\
\text { Coefficients } \\
\text { Beta } \\
\end{array}$} & \multirow[b]{2}{*}{ B } & \multirow{2}{*}{$\begin{array}{c}\text { Sig. } \\
\text { Std. Error }\end{array}$} \\
\hline & & B & Std. Error & & & \\
\hline \multirow[t]{3}{*}{1} & (Constant) & 30.331 & 20.878 & & 1.453 & .155 \\
\hline & $\begin{array}{l}\text { Kualitas_Priba } \\
\text { di }\end{array}$ & 1.050 & .801 & .208 & 1.311 & .198 \\
\hline & $\begin{array}{l}\text { Peran_orangtu } \\
\text { a }\end{array}$ & .835 & .443 & 299. & 1.883 & .068 \\
\hline
\end{tabular}

a Dependent Variable: Negatif_Internet

$$
\begin{array}{ll}
\mathrm{Y}=1,453+1,311 \mathrm{X} 1+1,883 \mathrm{X} 2 \\
\mathrm{Y} & =\text { Peran Negatif Internet } \\
\mathrm{X} 1 & =\text { Kualitas Pribadi Anak } \\
\mathrm{X} 2 & =\text { Peran Orang Tua }
\end{array}
$$

\footnotetext{
${ }^{23}$ C. George Boeree, General Psychology, (Jogjakarta : Prismasophie, 2008), 384

${ }^{24}$ Jonthan dan Lucy Bartley, Internet dan Anak Anda, (Yogyakarta : Andi Offset, 2008), 93

${ }^{25}$ Ibid. , 15

${ }^{26}$ Mary Go Setiawani, Pembaruan Mengajar, (Bandung : Yayasan Kalam Hidup, 2005) Cetakan Kelima,
} 
Jika meningkat peran orang tua kepada pembentukan kepribadian anak yang berkualitas pada setiap tahapannya yang anak lewati, ini berarti meningkat pula anak yang memiliki kepribadian yang berkembang kearah kepribadian yang berkualitas, maka meningkat pula anak yang menggunakan internet yang positif dan mengalami penurunan anak yang menggunakan internet untuk hal negatif dan penurunan juga kepada anak yang mengalami dampak negatif dari internet.

Tetapi pada data tabel, terlihat adanya sebagian besar anak yang memakai internet untuk hal-hal negatif, atau sebagian besar anak yang terkena dampak negatif dari internet. Peran orang tua yang memang memberikan pengaruh negatif kepada anak. Sehingga ada hubungan dengan pemakaian internet untuk hal-hal negatif dari internet. Dari hasil jawaban angket bagi orang tua dan anak tentang kualitas pribadi, dapat dijelaskan bahwa orang tua kurang berperan dalam pembentukan kualitas pribadi anak, dan anak juga mengaku bahwa mereka membutuhkan peran orang tua dalam pembentukan kualitas pribadi anak. Jadi karena orang tua kurang berperan, sehingga membawa negatif kepada anak, terutama kepada pribadi anak. Ini menyebabkan anak melakukan hal negatif, dan lewat internet mereka bisa lakukan. Jawaban yang tidak mereka dapatkan untuk memenuhi kebutuhan mereka, mereka dapat mencarinya di internet, dan anak dapat terkena dampak negatif dari internet.

Seperti yang dijelaskan Erikson bahwa "perkembangan ego lebih penting daripada fungsi-fungsi id dan dalam perkembangan ego ini pengaruh-pengaruh lingkungan sosial besar sekali." ${ }^{27}$ Makanya lingkungan sosial khususnya orang tua sangat berpengaruh terhadap pembentukan ego. Ego inipun berpengaruh terhadap lingkungan sosial anak. Erikson mangatakan bahwa "perkembangan ego sikap anak tumbuh melalui tahapan yang dapat diramalkan dan tahapan ini tidak terbatas pada waktu anak itu masih kanakkanak, perlu diingat anak terus berkembang dan bertumbuh sampai usia tua." Perhatian dan kasih sayang tidak terbatas pada waktu anak masih kanak-kanak, perlu diingat anak terus berkembang dan bertumbuh sampai tua." ${ }^{28}$ Berarti kualitas pribadinya berkembang sehingga orang tua tetap perlu memperhatikan, tidak berhenti pada masa kanak-kanak saja. Apalagi anak itu masuk masa remaja, banyak perubahan yang terjadi pada masa remaja, disinilah peran orang tua bagi remaja. Ulangan 6:6-7 mengatakan " apa yang kuperintahkan kepadamu pada hari ini haruslah engkau perhatikan, haruslah engkau mengajarkannya berulang-ulang kepada anak-anakmu dan membicarakannya apabila engkau duduk di rumahmu, apabila engkau sedang dalam perjalanan, apabila engkau berbaring dan apabila engkau bangun. ${ }^{29}$ Dalam segala kesempatan ingatkanlah berulangulang tentang Firman Tuhan, melalui ibadah bersama, orang tua dapat mengajar Firman Tuhan kepada anak. Anak yang sudah remaja lebih banyak belajar dari pengalaman, dari persekutuan ibadah bersama akan menuntun anak memperbanyak pengalaman dengan Tuhan. Dari persekutuan ini remaja dapat berdiskusi tentang Firman Tuhan, dan berdiskusi tentang kegiatan remaja seharian itu. “ Meskipun mereka bosan tetapi kita tetap harus mengajarkannya, pengulangan itu akan membentuk karakter mereka." 30 Remaja memang akan bosan dengan pengajaran Firman Tuhan yang selalu diulang-ulang, tetapi orang tua jangan menyerah tetap lakukan pengajaran Firman Tuhan ini. Pengajaran Firman Tuhan dapat menjadi filter untuk menyaring hal-hal yang negative dari lingkungan.

${ }^{27}$ Mary Go Setiawani, Pembaruan Mengajar, (Bandung : Yayasan Kalam Hidup, 2005) Cetakan Kelima,

29

${ }^{28}$ Ibid. , 92

${ }^{29}$ Julianto Simanjuntak dan Roswitha Andraha, Mendidik Anak Seuai Zaman dan Kemampuannya, (Tangerang : Lk3, 2007), 103

${ }^{30}$ Ibid. , 104 
"Jangan pernah berhenti untuk mendoakan anak-anak kita."3l Orang tua jangan pernah berhenti mendoakan anak-anak, karena perkembangan zaman, banyak hal-hal negatif disekitar anak, dan hal-hal negatif itu dengan mudah dapat ditemui anak. Tiap hari anak remaja berada pada lingkungan itu, ada hal negatif dan ada hal positif. Hanya Tuhan yang tahu apa yang dilakukan oleh remaja diluar, dan tidak mungkin orang tua mengikuti remaja. "Ceritalah kepada Tuhan tentang mereka dan doakanlah terus menerus." 32 Ceritalah kepada Tuhan, tentang remaja tentang kegelisahan orang tua yang berkaitan dengan remaja, dan apa saja yang akan dihadapi oleh remaja. Hanya Tuhan yang bisa melindungi remaja dari hal-hal negatif yang diberikan internet, dan Tuhan juga yang bisa melindungi remaja dari dampak negatif internet.

"Ajarkanlah anak itu dengan ajaran Tuhan berulang-ulang."33 Dalam segala kesempatan ingatkanlah remaja tentang Firman Tuhan, melalui ibadah bersama. Orang tua dapat mengingatkan tentang Firman Tuhan, remaja juga dapat belajar tentang Firman Tuhan dari ibadah bersama. "Kalau anak-anak kita sudah menerima dan memahami nilainilai kebenaran dari Firman Tuhan, maka dia bisa membedakan apa yang salah dan apa yang benar." ${ }^{34}$ Ini akan membuat remaja dapat mengambil keputusan yang sesuai dengan apa yang sudah dia pelajari dan dia terima dari Firman Tuhan, sehingga imannya berkembang. Sehingga remaja dapat mengatasi tantangan yang menghasilkan dampak negatif dari internet kepada remaja.

\section{KESIMPULAN}

Berdasarkan hasil penelitian dan pembahasan Bab IV, maka dapat ditarik kesimpulan sebagai berikut:

Pertama, hubungan orang tua dan kualitas pribadi anak masih kurang, ini karena terdapat fakta bahwa kepribadian anak kurang berkembang kearah kepribadian yang berkualitas, karena kurangnya peran orang tua mempengaruhi kualitas pribadi anak..

Kedua, pengaruh peran orang tua kepada kualitas pribadi anak masih kurang, sehingga hanya memberikan pengaruh negatif kepada kualitas pribadi anak, sehingga anak kurang memakai internet untuk hal positif.

Ketiga, pengaruh peran orang tua kepada kualitas pribadi anak yang hanya memberikan pengaruh negatif, sehingga anak menggunakan internet untuk hal negatif semakin meningkat.

\section{Saran-Saran}

Ada beberapa hal penulis hendak sampaikan melalui penulisan karya ilmiah ini :

Pertama, Bagi orang tua bina hubungan yang baik dan akrab dengan Allah, jadikan Allah sebagai patokan atau teladan di dalam kehidupan.

Kedua, alami kuasa dan pertolongan Allah, melalui komunikasi dengan Allah yaitu doa yang dinaikan setiap hari, dan pertolongan Allah dari Firman Tuhan yang direnungkan setiap hari.

Ketiga, agar lebih teratur saat teduhnya, pergunakan buku renungan yang diatur dalam seminggu atau dalam setahun.

Keempat, adakan setiap minggu ibadah bersama, agar anak dapat belajar Firman Tuhan, dan diadalamnya dapat berdoa bersama, tanyakan kepada anak cita-cita mereka atau apa yang mereka ingin lakukan pada masa depan agar dapat berdoa bersama.

\footnotetext{
${ }^{31}$ Julianto Simanjuntak dan Roswitha Andraha, Mendidik Anak Seuai Zaman dan Kemampuannya, (Tangerang : Lk3, 2007), 103

${ }^{32}$ Ibid. , 103

${ }^{33}$ Ibid. , 94

${ }^{34}$ Ibid. , 220
} 
Kelima, ajarkan kepada anak mendoakan secara pribadi tentang kehidupan mereka, dan ajarkan mereka merenungkan Firman Tuhan melalui buku renungan yang orang tua berikan.

Keenam, tunjukkan kepada anak kedisiplinan dan kejujuran kepada anak dalam kehidupan sehari-hari.

Ketujuh, dalam ibadah bersama, diskusikan apa yang anak lakukan selama seminggu itu, berikan kesempatan anak untuk berbicara dan mengutarakan pendapat mereka dalam diskusi.

Kedelapan, hargai dan terima perbedaan generasi, karena generasi orang tua itu beda dengan generasi anak. Maka orang tua perlu mengikuti perkembangan jaman, orang tua perlu mempelajari teknologi yang lagi berkembang seperti internet.

Kesembilan, perlajari internet lewat buku atau langsung menggunakan internet itu, karena orang tua perlu mengetahui pengaruh positif dan pengaruh negatif yang diberikan internet.

Kesepuluh, coba diskusikan pengaruh negatif dan pengaruh positif internet kepada anak, dan berikan kesempatan kepada anak mengutarakan pendapat tentang internet.

Kesebelas, orang tua jangan berhenti mendoakan anak, karena pengaruh negatif sering dihadapi anak dalam kehidupan sehari-hari, hanya doa yang dapat menjaga mereka dari pengaruh negatif. Orang tua juga perlu mendoakan teman-teman yang berada dilingkungan anak, supaya teman-teman yang memberikan pengaruh positif masuk dalam kehidupan anak.

Kedua belas, orang tua berikan kasih sayang dang perhatian kepada anak, dengan memberikan kata-kata kasih sayang yang dapat membangun semangat mereka, berikan pelukan saat anak sedang putus asa atau dalam masalah, layani anak dalam memenuhi kebutuhan mereka, berikan mereka waktu, dengarkan curhat mereka atau pendapat mereka, atau kegelisahan mereka karena masa remaja masa dimana anak sering menghadapi kegelisahan karena perubahan yang terjadi.

Ketiga belas, bagi gereja berikan pembinaan Firman Tuhan kepada orang tua tentang peran orang tua kepada anak berkaitan dengan Firman Tuhan, seperti program pendalaman Firman Tuhan.

Keempat belas, bagi gereja mengadakan program seminar pelayanan anak dan remaja kepada orang tua, atau mengundang pembicara yang mengerti dan dapat menjelaskan kepada orang tua cara mendidik anak, karena masih banyak orang tua yang tidak mengerti cara mendidik anak.

Kelima belas, bagi gereja dapat menyusun program renungan setiap minggunya ibadah dalam keluarga untuk masing-masing keluarga, agar ibadah dalam keluarga bisa lebih efektif. Karena dalam ibadah keluarga sering terjadi diskusi antara orang tua dan anak.

Keenan belas, bagi gereja berikan pembinaan tentang doa kepada orang tua, berikan penjelasan tentang pentingnya mendoakan anak dan cara mendoakan anak.

Ketujuh belas, bagi sekolah theologia khususnya dosen, perlu ada pembinaan kepada mahasiswa tentang kepribadian Kristen, karena kebanyakan mahasiswa menggunakan internet secara negatif. Perlu diketahui mahasiswa ada yang masuk dalam kategori remaja.

Kedelapan belas, bagi sekolah theologia, berikan pembinaan kepada mahsiswa tentang internet, dan juga pengaruh internet kepada mahasiswa. Karena mahasiswa masih banyak yang belum mengerti tentang pengaruh negatif yang diberikan internet ini berkaitan dengan pemanfaatan interent yang berlebihan. Kebanyakan mahasiswa memakai internet sampai larut malam, ini dapat merugikan kesehatan mereka, dan juga banyak mahasiswa jadi tidak bertanggung jawab dengan tugasnya. 


\section{KEPUSTAKAAN}

\section{Buku-Buku}

Bartley, Jonathan dan Lucy. Internet Dan Anak Anda. Yogyakarta : Andi, 2001

Boeree, C. George. General Psychology. Jogjakarta : Prismasophie, 2008.

Eyre, Linda dan Richard. Mengajarkan Nilai-Nilai Kepada Anak. Jakarta : Gramedia Pustaka Utama, 1999.

Gunarsa, Singgih D. Dasar Dan Teori Perkembangan. Jakarta : Bpk Gunung Mulia, 1982.

Narramore, Clyde M. Menolong Anak Anda Bertumbuh Dalam Iman. Bandung : Kalam Hidup, 1961.

Setiawani, Mary Go. Pembaruan Mengajar, Cetakan kelima Bandung : Yayasan Kalam Hidup, 2005

Shelly, Judith Allen. Kebutuhan Rohani Anak. Bandung : Kalam Hidup.

Simanjuntak, Julianto dan Roswitha Andraha. Mendidik Anak Sesuai Zaman dan Kemampuan. Tangerang : Lk3, 2007.

Subagyo, Andreas B. Pengantar Riset Kuntitatif Dan Kualitatif. Bandung : Yayasan Kalam Hidup, 2004.

Sumanto. Metodologi Penelitian Sosial \& Pendidikan. Yogyakarta: Andi Affiset, 1990.

Surakhman Winarno. Dasar \& Teknik Research Pengantar Metodologi Ilmiah. Bandung: Tansito, 1978.

\section{Wawancara}

Age. Wawancara Oleh Penulis, Makassar, Sulawesi Selatan, 0l Agustus 2009.

Andre. Wawancara Oleh Penulis, Makassar, Sulawesi Selatan, Ol Agustus 2009.

Delly. Wawancara Oleh Penulis, Makassar, Sulawesi Selatan, 26 Mei 2009.

Jessica. Wawancara Oleh Penulis, Makassar, Sulawesi Selatan, 03 Agustus 2009. 